\title{
Application of fuzzy logic approach for the determination of the integral index of the implicit impact of the higher education system on regional development (on the example of Ukraine)
}

\author{
Oksana Sotula ${ }^{1}$, and Viktoriya Denysenko ${ }^{1,{ }^{*}}$ \\ ${ }^{1}$ Bohdan Khmelnytsky National University of Cherkasy, Department of Economics and International Economic Relations, 81, \\ Shevchenko Boulevard, 18031, Cherkasy, Ukraine
}

\begin{abstract}
In this paper the theoretical and methodological aspects of the influence of the higher education system on the socio-economic development of the regions of Ukraine are considered. On the basis of fuzzy logic approach, we have calculated the integral index of the implicit impact (IIII $=\mathrm{I}^{4}$ ) of the higher education system on regional development. Regions are grouped by this indicator over time. The integral indicator allowed us to identify regions with the corresponding $\mathrm{I}^{4}$ of the higher education system at the regional level and compare them with other regions of Ukraine (identification of inter-regional imbalance). The analysis shows that there is no strategy for embedding the university in the local economy and society. It is impossible to state unequivocally that the most developed regions have the greatest influence on the system of higher education, and vice versa. An important continuation of the study should be an assessment of the situation in each region of the country separately. Such analytics should help develop differentiated directions for the development of regional higher education systems.
\end{abstract}

\section{Introduction}

Over the past few decades, the evaluation of university contributions to the economic, social, cultural and innovative development of society has been central to educational policy issues. In higher education systems of economically developed countries, radical transformations are taking place that are associated with the increasing importance of universities for innovative development and economic growth. The two main objectives of each university are education and science. However, there is a growing awareness that universities are becoming enterprises with corresponding functions in the economy and society, except for school and laboratory. They begin to position themselves as engines of regional development. From the middle of the 20th century, the state policies of developed countries are aimed at developing human capital, regional disparities of which may undermine national security.

The issue of the role of higher education institutions in stimulating the development of the regional economic system is being actively discussed in the scientific literature today. Thus, the studies of P.H. Pellenbarg [1], A. Valero, and J.V. Reenen [2] are devoted to the calculation of the quantitative contribution of universities to regional development.

G. Huggins, P. Cook, D. Charles, P. Benneworth, G. Etzkowitz, D. Bock, etc. [3] evaluate the contribution of universities to the innovative development of regions, analyze how universities can produce not only new knowledge and technologies, but also implement them in regional socio-economic and production systems [4].
Eliot, Levin and Mazil consider universities as generators of economic development of the region at the expense of funds invested in education in the form of state financing, tuition fees and living expenses for students from other regions, industrial orders [5].

The aforementioned approach expanded B. Bluestone [6] by adding to the criteria for assessing the impact of higher education on the regional economy an assessment of the level of qualifications of workers. According to this approach, universities train and produce more skilled workers who have higher labor productivity, higher levels of income and consumption, and therefore, provide higher tax deductions to the budget.

However, the methodology for assessing the integrated impact of the higher education system on regional development is insufficiently developed.

Therefore, the aim of the article is to study the implicit impact of the higher education system on the socio-economic development of the region. This will provide an opportunity to develop practical mechanisms for ensuring balanced regional development.

To achieve this goal, we use the following methods: theoretical generalization, comparison and systematization (in the study of the nature and effects of the impact of the higher education system on the development of regions). Abstract-logical method (for theoretical generalization), the index method in context with the mathematical apparatus of the theory of fuzzy sets (for determining the integral index of the implicit impact of the higher education system on regional development), the graphical method (for visualizing the relationship between input and output variables).

\footnotetext{
* Corresponding author: vikaonline@ukr.net
} 


\section{Results}

The influence of the higher education system on the socio-economic development of the region is increasingly becoming the center of research for domestic and foreign scientists. Reality indicates a change in the socio-economic goals of the university. From its first generation (educational institution only), to the second generation university (training and research), and the third generation university (integrated educational, research and business environment).

Today we are talking about fourth-generation universities. Its exact characteristics are still insufficiently investigated. The essential difference of such a university is the availability of a strategic approach to its own development and the ability to actively influence the competitiveness of the regional environment [7].

We believe that the growth of influence on regional development can be expected already from thirdgeneration universities, because it is here that not only education and research, but also the use of knowledge become important. As a result, the relationship between production and universities is deepening, so there is the possibility of local use of knowledge created in universities. This increases the competitiveness of enterprises and, as a result, the region. In addition, the social environment of universities is improving. A knowledge-based society is inevitably linked to the valuation of human capital, since the competitiveness of an economy depends on the quantity and quality of available human resources.

There are several classifications of areas and types of university influence on the regional system. According to R. Florax, there are eight regional effects of university activities in the demographic subsystem, economic subsystem, infrastructure, culture, attractiveness of the region, education, social subsystem, political subsystem [1].

There are short-term and long-term impacts of universities on the region's economy. In the short term, there is an impact on the demand of local enterprises, the income and expenses of local households, and the services and income of local governments. The longterm impact on the university is the qualification of human capital, attracting foreign capital and labor in the immediate vicinity of the university and the number of enterprises based on university research. These factors can be considered as having a secondary regional multiplicative effect, since they heighten the demand for local goods and services [8].

Regional and local effects of the university can be observed in many areas outside the economy. As a rule, three types of economic influence of universities are evaluated in research: direct, indirect, and induced [9].

In our opinion, the most comprehensive by the nature of the impact of the classification of the results of university activities should take into account the type of impact on the regional subsystem (Table 1).

It is clear that the selected areas are not isolated from each other but have different effects. The most significant activity of the university affects the economic subsystem, which is closely linked to the demographic changes, infrastructure, educational system and image of the region.

Table 1. Types of university influence on regional subsystems.

\begin{tabular}{|l|c|c|c|c|}
\hline \multirow{2}{*}{ Regional subsystems } & \multicolumn{3}{|c|}{ Types of university influence } \\
\hline & Direct & Indirect & Induced & Catalytic \\
\hline Demographic & $\vee$ & $\vee$ & $\vee$ & $\vee$ \\
\hline Economic & $\vee$ & $\vee$ & $\vee$ & $\vee$ \\
\hline Infrastructure & $\vee$ & $\vee$ & $\vee$ & $\vee$ \\
\hline Culture & $\vee$ & $\vee$ & $\vee$ & $\vee$ \\
\hline Attractiveness & & & & $\vee$ \\
\hline Education & $\vee$ & $\vee$ & $\vee$ & $\vee$ \\
\hline Social & & & & $\vee$ \\
\hline Political & & & & $\vee$ \\
\hline
\end{tabular}

The economic impact of a higher educational establishment is defined as the difference between the existing level of economic activity in the region and the level that could have been if the institution did not exist [10].

However, the quantitative assessment of the impact of universities on the regional subsystem is complicated by the presence of the implicit impact of the higher education system on regional development.

Implicit mechanisms are based on mechanisms of different order. Its characteristics are manifested in human activity in different ways. In psychology, it is associated with the implicit personality theory, which allows you to form a holistic impression of another person based on incomplete information about his personal characteristics. Mathematicians and other representatives of the exact sciences are concentrating their efforts in developing data search and recovery algorithms based on implicit factors that influence various processes. In economics, the term «implicit» is associated mainly with «intangible», «immeasurable», «elusive» factors that affect the economic activity of an economic agent. Thus, implicit factors are implicit, hidden factors, production resources, which in the course of economic activity do not find direct, official reflection [11].

Implicit impact (the influence of implicit factors) is an implicit influence within the economic system that can lead to a synergistic effect. This effect is that when the subject achieves significant economic results, an area of unstable conditions arises. A minor hidden influence of external forces can lead to diametrically opposite development vectors: from the collapse of the system to a new, higher level of development. The nature of implicitness lies in the presence of hidden (implicit) information that circulates in the economic environment and requires decision-making after in-depth analysis of data in order to obtain the most complete information. In our case, implicitness is understood as the impossibility to take into account all aspects of the impact under study, since in the process of analysis, hidden, implicit, unaccounted information appears in the datainformation-knowledge chain.

In our opinion, the urgent task is to construct an integral index of the implicit impact $\left(\mathrm{IIII}=\mathrm{I}^{4}\right)$ of the 
higher education system on regional development and to group the regions according to this indicator.

To construct the integral index, we used the index method in context with the mathematical apparatus of the theory of fuzzy sets (fuzzy logic and Mamdani fuzzy logical inference) [12], which allows to use of heterogeneous input variables, formalize nonlinear dependencies, use natural language to describe the connection, and obtain fuzzy models that are flexible for tuning and adaptation. The main stages of constructing a Mamdani fuzzy logical inference are as follows:

1) determination of the main factors (parameters) of the system under consideration;

2) determination and formalization of linguistic variables (fuzzification);

3) the construction of a fuzzy knowledge base (fuzzy production rules);

4) implementation of a fuzzy inference;

5) reducing the fuzzy value of the output variable into a clear one using the center of gravity method (defuzzification).

Note that the index method of determining the integral index involves the following steps:
1) the choice of indicators characterizing the phenomenon;

2) statistical analysis and standardization (normalization) of data;

3 ) the calculation of the partial indices (sub-indices);

4) determination of the resulting integral index on the basis of sub-indices;

5) analysis and interpretation of the result.

In our study, the main blocks (sub-indices) of the $\mathrm{I}^{4}$ of the higher education system in the socio-economic development of the regions are economic, innovative, educational and demographic (see Table 2).

Each of these partial indices will be determined using three indicators (stimulators). According to the classical scheme, the aggregate index consists of partial indices and is represented in the form of their weighted sum or product. The selection of indicators for the evaluation of each of the blocks is based on the presented theoretical approaches, but takes into account the features of the domestic system of higher education and the factors associated with the characteristics of data collection.

Table 2. The list of indicators characterizing sub-indices.

\begin{tabular}{|c|c|c|c|}
\hline $\begin{array}{c}\text { Sub- } \\
\text { indices }\end{array}$ & Indicators (stimulators) & $\begin{array}{c}\text { Economic contribution of the } \\
\text { university }\end{array}$ & Regional effect \\
\hline \multirow{3}{*}{ 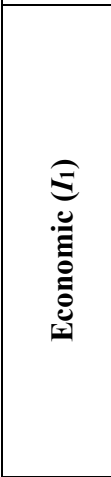 } & $X_{1}-$ GRP per capita, UAH. & $\begin{array}{l}\text { Impact on the regional } \\
\text { economy, budget revenues, } \\
\text { industrial structure, labor } \\
\text { market, labor mobility }\end{array}$ & $\begin{array}{l}\text { Wages, purchase of equipment, goods and } \\
\text { services (direct). Income and expenditures of } \\
\text { participants in university supply chains (indirect). } \\
\text { Income and employment are caused by the } \\
\text { multiplicative effect of income and expenditures } \\
\text { of employees, both of the university and its } \\
\text { associated companies (induced). }\end{array}$ \\
\hline & $\begin{array}{l}X_{2}-\text { GRP per worker of working age, } \\
\text { UAH. }\end{array}$ & $\begin{array}{l}\text { Impact on the level of } \\
\text { education, structure and } \\
\text { quality of labor in the region }\end{array}$ & $\begin{array}{l}\text { Providing the labor market with highly skilled } \\
\text { labor, the growth of labor productivity in the } \\
\text { region (catalytic). }\end{array}$ \\
\hline & $\begin{array}{l}X_{3}-\text { Small and medium business (SME) } \\
\text { per } 10 \text { thousand population, units. }\end{array}$ & $\begin{array}{l}\text { Companies that are created by } \\
\text { students (former) and } \\
\text { university staff }\end{array}$ & $\begin{array}{l}\text { Income and employment in companies that are } \\
\text { formed thanks to the university (catalytic). }\end{array}$ \\
\hline \multirow{3}{*}{ 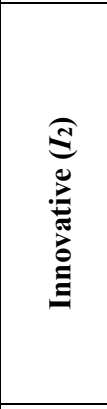 } & $\begin{array}{l}X_{1}-\text { Distribution of applications for } \\
\text { inventions and utility models addressed } \\
\text { to national applicants by region. }\end{array}$ & \multirow{3}{*}{$\begin{array}{l}\text { Selling knowledge in the form } \\
\text { of patents, regional value } \\
\text { added in the field of } \\
\text { information technology }\end{array}$} & Income from research activities (direct). \\
\hline & $\begin{array}{l}X_{2}-\text { Regional gross value added in the } \\
\text { field of information and } \\
\text { telecommunications (IT companies) } \\
\text { (UAH per capita). }\end{array}$ & & $\begin{array}{l}\text { Jobs created by the functioning of the university } \\
\text { (direct). Income and employment are caused by } \\
\text { the multiplicative effect of income and } \\
\text { expenditures of employees in the IT sector } \\
\text { (induced). }\end{array}$ \\
\hline & $\begin{array}{l}X_{3}-\text { Organizations that carried out } \\
\text { research and development, per } 10 \\
\text { thousand population, units. }\end{array}$ & & $\begin{array}{l}\text { Government funding, business income, income } \\
\text { and employment in organizations that carry out } \\
\text { research and development (catalytic). }\end{array}$ \\
\hline \multirow{3}{*}{ 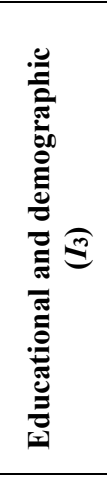 } & $\begin{array}{l}X_{1}-\text { Economically active population } \\
\text { aged } 15-70 \text { years, number of people by } \\
\text { level of education per } 10 \text { thousand } \\
\text { population. }\end{array}$ & \multirow{3}{*}{$\begin{array}{l}\text { The impact on the level, } \\
\text { structure and quality of } \\
\text { education in the region. } \\
\text { Population growth, changing } \\
\text { population structure and } \\
\text { mobility. }\end{array}$} & $\begin{array}{l}\text { Providing the labor market with highly skilled } \\
\text { labor, flexible supply of student labor (induced). }\end{array}$ \\
\hline & $\begin{array}{l}X_{2}-\text { Number of institutions of higher } \\
\text { education per } 10 \text { thousand population. }\end{array}$ & & $\begin{array}{l}\text { Provision of educational services (direct). } \\
\text { Income and expenditures of employees of the } \\
\text { university and related institutions (indirect). } \\
\text { Income and employment caused by the } \\
\text { multiplicative effect of income and expenditures } \\
\text { of employees (induced). }\end{array}$ \\
\hline & $\begin{array}{l}X_{3}-\text { Number of students, per } 10 \\
\text { thousand population. }\end{array}$ & & $\begin{array}{l}\text { Expenditures for the purchase of goods and } \\
\text { services, tuition fees (direct). } \\
\text { Increase in labor force (induced). }\end{array}$ \\
\hline
\end{tabular}


It should be noted that the procedure for determining the weight coefficients of the components of the general index is labor intensive, since it is necessary to take into account considerable achievements in this sphere and cover a large number of judgments, even often incomparable. But using the methods of the theory of fuzzy sets allows us to avoid these difficulties in determining weight coefficients.

For calculations, only the normalized (standardized) values of the parameters belonging to the segment $[0,1]$ are used. The process of normalization of indicators is carried out according to the formula:

$z_{i}=\left(X_{i}-X_{\min }\right) /\left(X_{\max }-X_{\min }\right)-$ normalized values of the indicator in the $i$-th region.

The main idea of obtaining a resulting index is as follows.

1) Each sub-index is considered as the output variable in the Mamdani algorithm, and the corresponding indicators that characterize this partial index are used as input linguistic variables, moreover all input and output variables containing three terms: L (low), M (medium), H (high).

2) The general index $\left(\mathrm{I}^{4}\right)$ is considered as the output variable in the Mamdani algorithm, and the sub-indices that characterize this general index (and found in the previous step) are already used as input linguistic variables (Figure 1), moreover all the input variables containing three terms: L (low), M (medium), H (high), and the output variable - L (low), BM (below medium), $\mathrm{M}$ (medium), AM (above medium), H (high).

The procedure for finding sub-indices and the overall integral indicator is conducted for a specific year for all regions of Ukraine and their grouping is performed according to this indicator. Each term corresponds to a fuzzy set, which is given by the corresponding membership function. The specific form of membership functions is determined on the basis of various additional assumptions about the properties of these functions, taking into account the specificity of the existing uncertainty and the actual situation, expert data, etc. For our fuzzy model of determining the integral index we use the trapezoidal membership functions (Fig. 1). Formalized representations of input and output variables are obtained by means of Matlab fuzzy logic toolbox [13].

Then the structural identification of the model is carried out with the help of forming a fuzzy base of the production rules «IF-THEN» that reflect the connection of the «input-output».

The set of fuzzy production rules for the given knowledge base has the form:

IF $\left(I_{1}=L\right)$ and $\left(I_{2}=L\right)$ and $\left(I_{3}=L\right)$ or $\ldots$ or $\left(I_{1}=L\right)$ and $\left(I_{2}=L\right)$ and $\left(I_{3}=M\right)$, THEN $I=L$;

IF ..., THEN ...;

IF $\left(I_{l}=M\right)$ and $\left(I_{2}=H\right)$ and $\left(I_{3}=H\right)$ or $\ldots$ or $\left(I_{l}=H\right)$ and $\left(I_{2}=H\right)$ and $\left(I_{3}=L\right)$, THEN $I=A M$.

A fuzzy logical inference is implemented, ranging from logical statements to fuzzy logic equations. Such equations are derived from the knowledge base by replacing the linguistic terms to the membership function, and the operations «and» and «or» to the operation of finding the minimum $(\wedge)$ and the maximum
( $v$ ) respectively, while the weight of rule is taken into account by multiplying the fuzzy expression by the corresponding value of weight:

$$
\mu^{b_{j}}\left(x_{1}, \ldots, x_{n}\right)=\underset{p=1, k_{j}}{\vee} w^{j p} \cdot \widehat{ }_{i=1, n} \mu^{j p}\left(x_{i}\right)
$$

where $b_{j}$ is the $j$-th term of output linguistic variable.

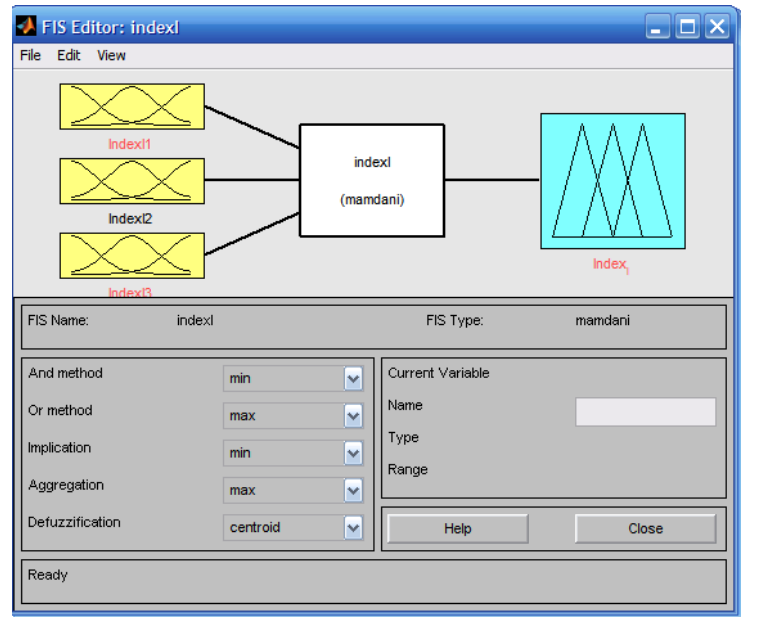

Fig. 1. Scheme of Mamdani fuzzy logical inference for the general integral index.

The system of fuzzy logic equations has the form:

$$
\begin{gathered}
\mu^{L}\left(I_{1}, I_{2}, I_{3}\right)=\left(\mu^{L}\left(I_{1}\right) \wedge \mu^{L}\left(I_{2}\right) \wedge \mu^{L}\left(I_{3}\right)\right) \vee \ldots \vee\left(\mu^{L}\left(I_{1}\right) \wedge \mu^{L}\left(I_{2}\right) \wedge \mu^{M}\left(I_{3}\right)\right), \\
\ldots . \\
\mu^{A M}\left(I_{1}, I_{2}, I_{3}\right)=\left(\mu^{M}\left(I_{1}\right) \wedge \mu^{H}\left(I_{2}\right) \wedge \mu^{H}\left(I_{3}\right)\right) \vee \ldots \vee\left(\mu^{H}\left(I_{1}\right) \wedge \mu^{H}\left(I_{2}\right) \wedge \mu^{L}\left(I_{3}\right)\right) .
\end{gathered}
$$

The final fuzzy set $\widetilde{I}$ is obtained as the union of all trimmed fuzzy subsets for each fuzzy rule:

$$
\widetilde{I}=\bigcup_{j=1}^{5} \int_{0}^{1} \frac{\min \left(\mu^{b_{j}}\left(I_{1}, I_{2}, I_{3}\right), \mu^{b_{j}}(I)\right)}{I} .
$$

Next, the fuzzy result is defuzzified by the method of the center of gravity, after which we obtain a clear value of the $\mathrm{I}^{4}$ at the regional level

$$
I=\frac{\int_{0}^{1} y \cdot \mu^{\widetilde{I}}(y) d y}{\int_{0}^{1} \mu^{\widetilde{I}}(y) d y} .
$$

Thus, on the basis of the indicated formulas and the methodology of fuzzy logic inference, we can obtain the value of the integral index for each region in the dynamics. To facilitate calculations, all phases of fuzzy simulation is performed by means of the Matlab fuzzy logic toolbox. After adjusting the parameters of the membership functions of the terms of input and output linguistic variables, the fuzzy knowledge base is filled. A visual presentation of the procedure of the fuzzy logic inference of Mamdani type and the defuzzification of the integral index is shown in Figure 2.

In the Figure 3 the visualization of the surfaces of the dependencies of the output linguistic variable from the other two input variables is presented. 


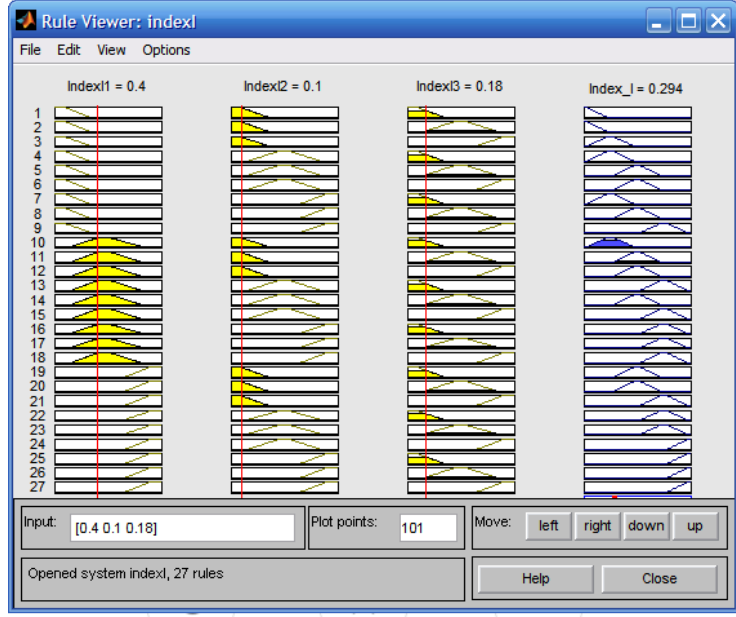

Fig. 2. Procedure for the fuzzy logic inference of Mamdani type (Zaporizhzhia region, 2016) $\mathrm{X}=[0.4 ; 0.1 ; 0.18]$.

As a result of the assessment, we obtained three subindexes of the higher education system: a contribution to the economic development of the region, a contribution to the innovative development of the region, and a contribution to the educational and demographic development of the region. The results of calculations for each of the sub-indices are presented in Table 3.

As you can see, the value of sub-index ranges from 0 - the worst, to 1 - the best value in the country. This allows us to represent all the regions of Ukraine in the order of the degree of their development for each of the sub-indices. At the same time, the place of the region in the uniform scale for Ukraine and the change in its potential is important. This makes it possible to consider changes in the integral index in a regional context and analyze the trends of each specific region.

The leaders in the sub-index of influence on economic development are Kiev, Poltava, Dnipropetrovsk and Zaporizhzhia regions. The presence of large universities in these regions explains the relatively high rates of income of universities.

On the second sub-index, besides Kiev, another region is leading - Kharkiv region. Here are located large national universities, which constitute a significant part of the regional innovation infrastructure.

The largest share of applications for inventions and utility models falls on the «Science» and «Education» sectors. Moreover, the number of applications submitted by educational institutions annually exceeds the number of applications submitted by scientific organizations. In 2016, the applicants of the Ministry of Education and Science of Ukraine submitted 2849 applications (this represents $37.9 \%$ of the total number of applications filed).

The most active among the organizations of the Ministry of Education and Science of Ukraine were institutions of higher education in the city of Kiev and the Kharkov region: National University of Food Technologies $(10.3 \%$ of the total number of applications filed by applicants from this ministry) National Technical University of Ukraine «Kiev Polytechnic Institute» (7.8\%), National Aerospace University. M.E. Zhukovsky Kharkiv Aviation Institute (4.3\%),
Kiev National University of Technology and Design and Vinnitsa National Technical University - 117 and 116 applications, respectively $(4.1 \%)$, National Technical University Kharkiv Polytechnic Institute - 91 applications (3 2\%), Odessa National Academy of Food Technologies -83 applications (2.9\%) [14].

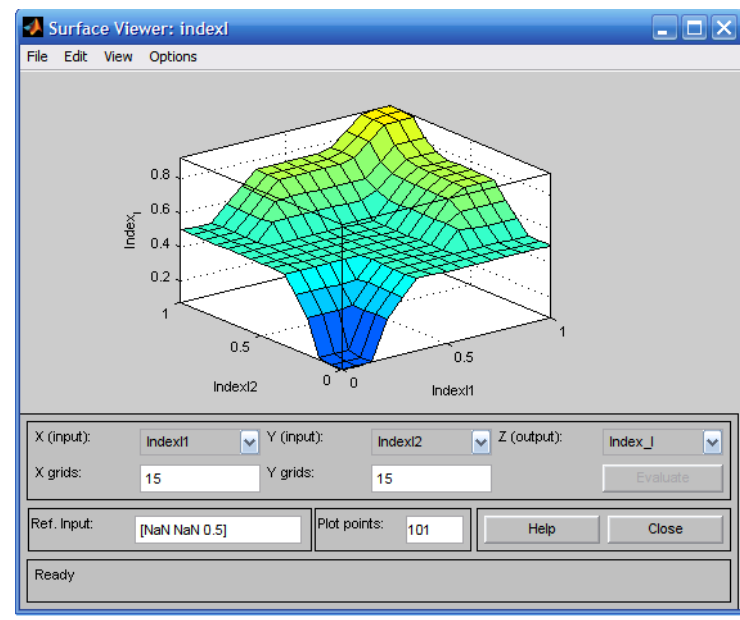

The surface of the dependence of the output of the fuzzy system $I$ on the input variables $I_{1}$ and $I_{2}$.

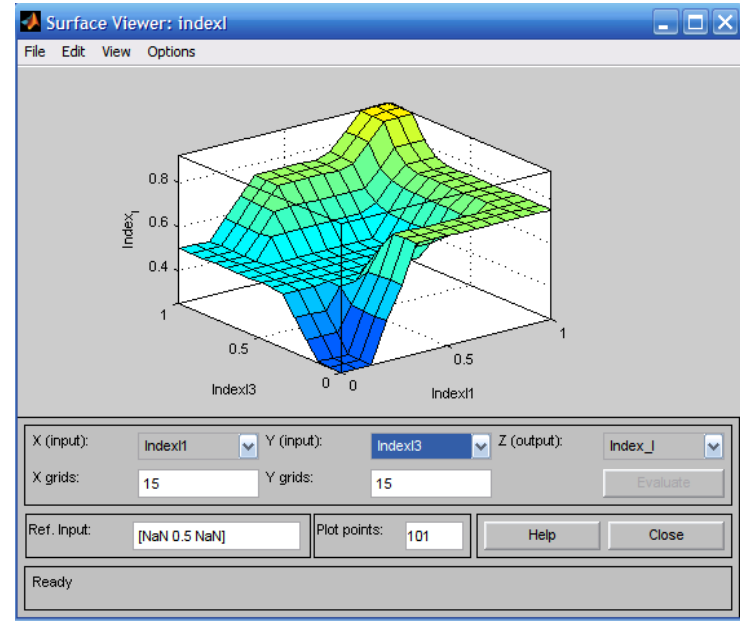

The surface of the dependence of the output of the fuzzy system $I$ on the input variables $I_{1}$ and $I_{3}$.

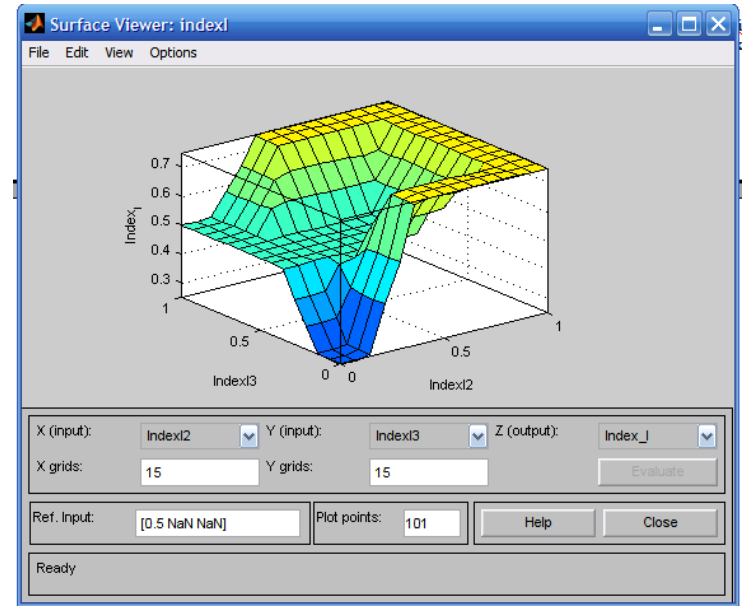

The surface of the dependence of the output of the fuzzy system $I$ on the input variables $I_{2}$ and $I_{3}$.

Fig. 3. Surfaces of the dependence of the output of the fuzzy system on the input variables. 
Table 3. Calculated values of the sub-indices and the integral index of the regions of Ukraine (2012/2016).

\begin{tabular}{|c|c|c|c|c|c|c|c|c|}
\hline \multirow{3}{*}{ Region } & \multicolumn{2}{|c|}{$\begin{array}{c}\text { Sub-index } \\
I_{1}\end{array}$} & \multicolumn{2}{|c|}{$\begin{array}{c}\text { Sub-index } \\
I_{2}\end{array}$} & \multicolumn{2}{|c|}{$\begin{array}{c}\text { Sub-index } \\
I_{3}\end{array}$} & \multicolumn{2}{|c|}{$\begin{array}{c}\text { Integral } \\
\text { index } I\end{array}$} \\
\hline & of the & year & of th & year & of the & year & of th & year \\
\hline & 2012 & 2016 & 2012 & 2016 & 2012 & 2016 & 2012 & 2016 \\
\hline Vinnytsia & 0.08 & 0.20 & 0.09 & 0.10 & 0.08 & 0.09 & 0.07 & 0.15 \\
\hline Volyn & 0.07 & 0.08 & 0.07 & 0.07 & 0.08 & 0.08 & 0.07 & 0.07 \\
\hline Dnipropetrovsk & 0.49 & 0.48 & 0.29 & 0.22 & 0.49 & 0.49 & 0.50 & 0.50 \\
\hline Donetsk & 0.45 & 0.09 & 0.23 & 0.08 & 0.50 & 0.13 & 0.50 & 0.08 \\
\hline Zhyto & 0.07 & 0.08 & 0.08 & 0.07 & 0.08 & 0.08 & 0.07 & 0.07 \\
\hline Zakarpattia & 0.07 & 0.08 & 0.08 & 0.07 & 0.08 & 0.08 & 0.07 & 0.07 \\
\hline Zaporizhzhia & 0.29 & 0.40 & 0.09 & 0.10 & 0.18 & 0.18 & 0.29 & 0.29 \\
\hline $\begin{array}{l}\text { Ivano- } \\
\text { Franki }\end{array}$ & 0.08 & 0.08 & 0.08 & 0.08 & 0.08 & 0.08 & 0.07 & 0.07 \\
\hline Kiev & 0.46 & 0.48 & 0.09 & 0.09 & 0.09 & 0.10 & 0.25 & 0.25 \\
\hline Kirovohrad & 0.08 & 0.22 & 0.08 & 0.08 & 0.08 & 0.08 & 0.07 & 0.12 \\
\hline Luhansk & 0.09 & 0.07 & 0.10 & 0.08 & 0.27 & 0.07 & 0.09 & 0.07 \\
\hline Lviv & 0.08 & 0.28 & 0.15 & 0.17 & 0.39 & 0.47 & 0.13 & 0.41 \\
\hline Mykola & 0.08 & 0.12 & 0.09 & 0.08 & 0.08 & 0.08 & 0.07 & 0.09 \\
\hline Odes & 0.18 & 0.33 & 0.10 & 0.09 & 0.35 & 0.43 & 0.23 & 0.48 \\
\hline Poltava & 0.44 & 0.50 & 0.08 & 0.08 & 0.09 & 0.08 & 0.21 & 0.25 \\
\hline Rivne & 0.07 & 0.08 & 0.07 & 0.07 & 0.08 & 0.08 & 0.07 & 0.07 \\
\hline Sumy & 0.08 & 0.08 & 0.07 & 0.07 & 0.08 & 0.08 & 0.07 & 0.07 \\
\hline Ternopil & 0.07 & 0.08 & 0.07 & 0.07 & 0.08 & 0.08 & 0.07 & 0.07 \\
\hline Kharki & 0.33 & 0.39 & 0.49 & 0.50 & 0.49 & 0.50 & 0.50 & 0.51 \\
\hline Khers & 0.08 & 0.09 & 0.08 & 0.08 & 0.08 & 0.08 & 0.07 & 0.08 \\
\hline Khmelnytskyi & 0.07 & 0.08 & 0.07 & 0.07 & 0.08 & 0.08 & 0.07 & 0.07 \\
\hline Cherkasy & 0.08 & 0.24 & 0.08 & 0.08 & 0.08 & 0.08 & 0.07 & 0.20 \\
\hline Cher & 0.07 & 0.08 & 0.08 & 0.08 & 0.08 & 0.08 & 0.07 & 0.07 \\
\hline Chernihiv & 0.08 & 0.09 & 0.07 & 0.07 & 0.08 & 0.08 & 0.07 & 0.07 \\
\hline city Kiev & 0.95 & 0.95 & 0.95 & 0.95 & 0.95 & 0.95 & 0.94 & 0.94 \\
\hline
\end{tabular}

The leaders in the framework of $\mathrm{I}^{4}$ on the higher education system for regional development are Kiev, Dnipropetrovsk, Lviv, Kharkiv and Odessa regions. These are regions with large university centers. Here the number of universities is $45.8 \%$ of the total in Ukraine (259 institutions out of 657).

The leaders in the contribution of higher educational institutions to the educational and demographic development of the region are Kiev, Kharkiv, Odessa, Lviv and Dnipropetrovsk regions.

According to the research of the CEDOS analytical center «Movement of applicants between the regions of Ukraine» in 2017 and 2018, only Kharkov, Kiev, Odessa, Lviv and Chernivtsi regions had a positive balance of arrival and departure. In other regions there was an outflow of graduates [15].

The results of the sub-indices of the regions of Ukraine for 2012 and 2016 have been summarized in the integral indicator of the implicit impact of the higher education system on regional development (see Table 3 ). Based on the data in Table 3 we have conducted a grouping of regions according to the $\mathrm{I}^{4}$ of the higher education system at the regional level, the results of which are given in Table 4.

Most regions of Ukraine have integral indicator values that are critically low, low, and below average. In addition, the belonging of regions to one or another group of indicators practically did not change in 2016 compared to 2012. Growth rates are observed in Vinnytsia (2.14), Kirovograd (1.71), Lviv (3.15),
Nikolaev (1.29), Odessa (2.09), Poltava (1.19), Kharkiv (1.02), Kherson (1.14), Cherkasy (2.86) regions. The integral indicator decreased in Donetsk $(0.16)$ and Luhansk (0.78) regions. But this is due primarily to the unfavorable situation in the East of Ukraine and the neglect in the statistical data of a part of the occupied territories. In the remaining regions, the integral index remained almost unchanged. The current situation indicates that there is no effective strategy of «embedding» universities in the local economy and society at both the national and regional levels.

Table 4. Grouping of Ukrainian regions by I I , 2012/2016.

\begin{tabular}{|c|c|c|c|}
\hline Year & $\begin{array}{c}\text { The } \\
\text { boundaries } \\
\text { of the } \\
\text { integral } \\
\text { indicator } \\
\end{array}$ & $\begin{array}{l}\text { The } \\
\text { meaning of } \\
\text { the integral } \\
\text { indicator }\end{array}$ & $\begin{array}{l}\text { Distribution of regions by } \\
\text { integral indicator }\end{array}$ \\
\hline \multirow{6}{*}{2012} & {$[0 ; 0.1)$} & $\begin{array}{l}\text { critically } \\
\text { low }\end{array}$ & $\begin{array}{c}\text { Vinnytsia. Volyn. Zhytomyr. } \\
\text { Zakarpattia. Ivano-Frankivsk. } \\
\text { Kirovohrad. Luhansk. } \\
\text { Mykolaiv. Rivne. Sumy. } \\
\text { Ternopil. Kherson. } \\
\text { Khmelnytskyi. Chernivtsi. } \\
\text { Cherkasy. Chernihiv }\end{array}$ \\
\hline & {$[0.1 ; 0.2)$} & low & Lviv \\
\hline & {$[0.2 ; 0.4)$} & $\begin{array}{l}\text { below the } \\
\text { average }\end{array}$ & $\begin{array}{l}\text { Zaporizhzhia. Kiev. Odessa. } \\
\text { Poltava }\end{array}$ \\
\hline & {$[0.4 ; 0.6)$} & average & $\begin{array}{c}\text { Dnipropetrovsk. Donetsk. } \\
\text { Kharkiv }\end{array}$ \\
\hline & {$[0.6 ; 0.8)$} & $\begin{array}{l}\text { above the } \\
\text { average }\end{array}$ & - \\
\hline & {$[0.8 ; 1]$} & tall & city Kiev \\
\hline \multirow{6}{*}{2016} & {$[0 ; 0.1)$} & $\begin{array}{l}\text { critically } \\
\text { low }\end{array}$ & $\begin{array}{l}\text { Volyn. Donetsk. Zhytomyr. } \\
\text { Zakarpattia. Ivano-Frankivsk. } \\
\text { Luhansk. Mykolaiv. Rivne. } \\
\text { Sumy. Ternopil. Kherson. } \\
\text { Khmelnytskyi. Chernivtsi. } \\
\text { Cherkasy. Chernihiv }\end{array}$ \\
\hline & {$[0.1 ; 0.2)$} & low & Vinnytsia. Kirovohrad \\
\hline & {$[0.2 ; 0.4)$} & $\begin{array}{l}\text { below the } \\
\text { average }\end{array}$ & $\begin{array}{c}\text { Zaporizhzhia. Kiev. Poltava. } \\
\text { Cherkasy }\end{array}$ \\
\hline & {$[0.4 ; 0.6)$} & average & $\begin{array}{c}\text { Dnipropetrovsk. Lviv. Odessa. } \\
\text { Kharkiv }\end{array}$ \\
\hline & {$[0.6 ; 0.8)$} & $\begin{array}{l}\text { above the } \\
\text { average }\end{array}$ & 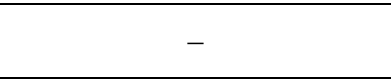 \\
\hline & {$[0.8 ; 1]$} & tall & city Kiev \\
\hline
\end{tabular}

\section{Conclusions}

The analysis suggests that there is no direct link between the sub-indices and the level of development of the regions. It is impossible to state unequivocally that the higher education system has the greatest influence on the most developed regions, and vice versa. The results obtained allow us to conclude that the degree of influence of the higher education system on regional development is a complex characteristic.

The obtained integral indicator allows only to single out regions with one $\mathrm{I}^{4}$ of the higher education system in comparison with others (identification of interregional imbalance). Even high values of the indicator do not mean that regional universities begin to play the role of 
centers of education and culture, or in general determine the level of the region.

An important continuation of the study should be an assessment of the situation in each region of the country separately. Such analytics will be able to provide indispensable assistance in determining the differentiated directions for the development of regional systems of higher education. Such systems should be focused on maximally promoting the development of territories, taking into account their specifics.

It is worth noting that the fuzzy model we have developed for determining the $\mathrm{I}^{4}$ can be refined and adapted to new data. Some input variables may be entered new or removed. One can extend the range of terms of linguistic variables etc. That is, the constructed model is flexible in setting and changing parameters. It does not require complex mathematical calculations (due to the use of Matlab).

\section{References}

1. Pellenbarg, P.H.: How to calculate the impact of a university on the regional economy. A case study of the University of Groningen, the Netherlands. http://www.rug.nl/staff/p.h.pellenbarg/artikelen/publ icaties $/ 13 . \% 20$ how $\% 20$ to $\% 20$ calculate $\% 20$ the $\% 20 \mathrm{i}$ mpact $\% 20$ of $\% 20 a \% 20$ university $\% 20$ on $\% 20$ the $\% 20$ regional\%20economy.pdf (2007). Accessed 18 Jan 2019

2. Valero, A., Reenen, J.V.: The economic impact of universities: evidence from across the globe. https://www.lampadia.com/assets/uploads_documen tos/95d91-valeromimeo2016.pdf (2016). Accessed 08 Jan 2019

3. Huggins, R., Johnston, A.: The economic and innovation contribution of universities: a regional perspective. Environ. Plann. C: Gov. Policy. 27(6), 1088-1106 (2009).

4. Benneworth, P., Charles, D.: University spin-off policies and economic development in less successful regions: Learning from two decades of policy practice. Eur. Plan. Stud. 13(4), 537-557 (2005). doi:10.1080/09654310500107175

5. Elliott, D.S., Levin, S.L., Meisel, J.B.: Measuring the economic impact of institutions of higher education. Res. High Educ. 28(1), 17-33 (1988). doi:10.1007/BF00976857

6. Bluestone, B.: UMASS/Boston: An Economic Impact Analysis. https://files.eric.ed.gov/fulltext/ED356733.pdf (1993). Accessed 03 Jan 2019

7. Zuti, B., Lukovics, M.: "Fourth generation" universities and regional development. https://mpra.ub.unimuenchen.de/77460/1/MPRA_paper_77460.pdf (2015). Accessed 03 Jan 2019

8. Lukovics, M., Zuti, B.: New functions of universities in century XXI towards "fourth generation" universities. J. Transit. Stud. Rev. 22(2), 33-48 (2015). doi:10.14665/1614-4007-22-2-003

9. Rol universytetiv v ekonomichnomu rozvytku mist, rehioniv, krainy (The role of universities in the economic development of cities, regions, and countries). https://www.csr-ukraine.org/wpcontent/uploads/2015/12/forum_publ_all_bezpolos_ print.pdf (2015). Accessed 24 Dec 2018

10. Kotosz, B., Gaunard-Anderson, M-F., Lukovics, M.: The local economic impact of universities: an international comparative analysis. https://www.researchgate.net/publication/28952073 3_The_Local_Economic_Impact_of_Universities_A $\mathrm{n}$ - International Comparative Analysis (2015). Accessed 14 Jan 2019

11. Rayzberg, B.A.: Sovremennyiy sotsioekonomicheskiy slovar (Modern socioeconomic dictionary). Moskva (2009)

12. Klir, G. J., Yuan, B.: Fuzzy sets and fuzzy logic: theory and applications. New Jersey (1995)

13. Matlab, Fuzzy Logic Toolbox 2.1. https://www.mathworks.fr/academia/student_versio n/r2009a products/fuzzylogic.pdf (2010). Accessed 24 Feb 2019

14. State statistics service of Ukraine. http://www.ukrstat.gov.ua (2019). Accessed $24 \mathrm{Feb}$ 2019

15. Rukh abituriientok ta abituriientiv mizh oblastiamy Ukrainy: porivniannia 2017 ta 2018 rokiv (Mobility of university applicants in Ukraine: comparison, 2017 and 2018 years). https://www.cedos.org.ua/uk/articles/rukhabituriientok-ta-abituriientiv-mizh-oblastiamyukrainy-porivniannia-2017-ta-2018-rokiv (2018). Accessed 10 Feb 2019 